\title{
Entrevista - Terrie Lisa Epstein: Educação histórica: quatro abordagens
}

Interview - Terrie Lisa Epstein: History Education: Four Approaches ${ }^{1}$

Entrevista realizada no dia 18 de maio de 2017, na sala de reuniões do Programa de Pós-Graduação em História da Faculdade de História da Universidade Federal de Goiás, Campus Samambaia. Goiânia.

Maria da Conceição Silva*

Marcelo Fronza ${ }^{\star *}$

Rafael Saddi Teixeira ${ }^{\star * *}$

Terrie Lisa Epstein - Hunter College/Department of Curriculum and Teaching - New York.

\section{EDUCATION}

Ed. D. Harvard Graduate School of Education - Dissertation: An Aesthetic Approach to Teaching and Learning History. M. A. Brandeis University History of American Civilization. Ed. M. Harvard Graduate School of Education - Administration, Planning and Social Policy. B. A. Brandeis University - History Major, graduated with honor - Junior Year Abroad in Mexico and Spain.

\section{BOOKS}

Epstein, T.; Peck, C. (Eds.) (in preparation). Research on teaching and learning difficult histories: Global concepts and contexts.

Chong, E. K.; Davies, I.; Epstein, T.; Peck, C.; Peterson, A.; Ross, A.; Schmidt, M.; Sears, A.; Sonu, D. Education, globalization, and the nation. Basingstoke, England: Palgrave Macmillan, 2015.

\footnotetext{
* Professora na Faculdade de História e no Programa de Pós-Graduação em História da Universidade Federal de Goiás, Campus Samambaia. Goiânia. mariacsgo@gmail.com

** Professor na Universidade Federal de Mato Grosso, Campus Cuiabá. Cuiabá. fronzam34@ yahoo.com.br

*** Professor na Faculdade de História e no Programa de Pós-Graduação em História da Universidade Federal de Goiás, Campus Samambaia. Goiânia. rafaelsaddiufg@gmail.com
} 
Epstein, T. Interpreting national history: Race, identity and pedagogy in classrooms and communities. New York: Routledge Press, 2009.

Turk, D.; Mattson, R.; Epstein, T.; Cohen, R. (Eds.). Teaching United States history: Dialogues between historians and teachers. New York: Routledge Press, 2009.

Snarey, J.; Epstein, T.; Sinkievicz, C; Zodhiates, P. (Eds.). Conflict and continuity: A history of ideas on social equality and human development. Cambridge: Harvard Educational Review, 1981.

A entrevista foi realizada sobre a conferência History Education: Four Approaches - proferida pela Professora Doutora Terrie Epstein.

\section{Terrie, can you tell us a little about the situation of the history education in the United States today?}

How it is taught or like what they learn?

\section{What they learn and how they learn.}

Ok. Now, first in elementary school almost no history is taught because federal policy "No Child Left Behind Act" says: "In elementary school we test English and we test math. History, forget about it". So, because young children are not tested in history, there is almost no history in elementary schools. But once they get to junior high school, middle school or secondary school, they do have history for two or three years of US History or one or two years of Global History. So, that is the curriculum. And in the US every state is a little different. In my state, NY, there are state exams in US History and Global History and if a student does not pass the exam they can't graduate from high school. So, in elementary school no history is taught, in secondary school history we call it "high-stakes" important, so that is the curriculum. How it is taught, now? There is a big movement to get students to be like we say "little historians", to learn history like a historian does history. So, it is not to memorize facts; it is to interpret primary and secondary sources and then use the evidence, the information of the sources to make an argument about a topic in history. So, for example: Should Truman have dropped the atom bomb? 
Right? No right answer, and the way to teach that question: you give students information from history that says yes, he should have dropped the atom bomb in Japan, and then you give them information that says no, he shouldn't have dropped the atom bomb in Japan, and then students have to take the information and make an argument: yes, no, maybe. So, that is now how secondary history is being taught or should be taught, because the high-stakes state test is about writing an essay about history and making an argument. African Americans have had many ways to fight segregation. Please explain some of the ways and which way do you think was more effective and why. So, like historical reasoning, historical thinking like Wineburg. That is what the schools now want teachers to teach secondary high school students. So, not memorize, but reason about history from historical sources.

Well, through questions, they will not say problems, because this view of teaching history is a) not political, just kind of technical in a sense of reason, you can reason, and you can ask the question you want to ask, but often the questions are not controversial, they are, you know, ordinary, like what were the reasons for Civil War. Something like that.

Good, and, in Europe, there is a great presence of the past, in the history of France, or Germany, or England, the whole Europe has a great presence of the past. History in the first sense, the facts of the humanities, the first war, the second war, and the holocaust, these kinds of things. Then, you see this kind of presence of the past in the United States, in the public sphere, in the politics, with the presence of Trump, and the whole discussion about this last election, for example.

Okay, now, when you say the past, you mean the past of the history of the countries?

No, the facts. This presence of the past.

Oh, the facts! Oh. The presence of the past in today. You know, unfortunately, Americans are not very big on history. Like you say, in Europe they talk more I think about their history in the present then we do. The people who tend to talk about the past are of course African Americans, Indians, because they will say the discrimination, the racism we face today comes from two, three, 
five hundred years of racism, but many white Americans, or even politicians, almost never. There was a time where people talked about World War II, and the heroes of WWII and how US sacrificed for WWII, but that was before, like, maybe, when I grew up, when I was young. Now, they don't talk about Vietnam, even. They barely talk about Iraq, and that is not even history. So, now, most white Americans don't tend to frame their contemporary, the reality, in terms of history, which is why we have Trump (laughter). Part of the reason!

\section{You have some problems with Rüsen's thoughts, because his idea of historical} consciousness is problematic, there are several reasons for that, but could you say something about that? What kind of problems you see in the theory of historical consciousness?

I'm going to tell you something that may be a bit surprise or may not. In the US, there are almost no history education professors who use Rüsen. Now Peter Seixas in Canada, he uses Rüsen. Dolinha (Maria Auxiliadora Moreira dos Santos Schmidt, Universidade Federal do Paraná) uses Rüsen. Europeans, some of them, use Rüsen. In the US, almost nobody. So, I started to read Rüsen because of Peter Seixas and because of Dolinha, who says Rüsen, Rüsen, Rüsen. Okay. So, then, I read Rüsen, I talk about him in my lecture for just two, three minutes and these are my thoughts, nobody else's. To me, the problem with Rüsen is kind of what we call apolitical, there is no politics. I mean, it is how the past, how people use the past to think about the present and the future. Well, what does that mean, exactly? And I have read Isabel Barca (Universidade do Minho, Portugal) has a research paper with Dolinha, so I've seen how people use his theory to do research with students but to me it is, I don't know, it doesn't take into account... I'm very interested in difference, and conflict, and how African American students, for example, in US, see US History differently than white students. And Rüsen doesn't really account for those kinds of things. I mean, he can, you can, I guess, talk more about it, but from what I've read, he has those levels, like, you know, less developed historical consciousness and more highly developed historical consciousness, but as you said, to me it is very kind of classical western, here is how we talk about history and some people have more developed ways of historical thinking. But, what about the problem that the history that we teach, in the US, that the government supports, they leave out of course, all the bad stuff, and Rüsen, I don't know 
how he accounts for that. He doesn't talk about, like, conflicting historical narratives. He doesn't talk about communities who feel their history is ignored, and, you know, maybe that is not what he wants to talk about. That is okay, but, for me, I think that has to be talked about, or else you are never questioning the official history and I think we need to teach young people to question the government's view of history and Rüsen doesn't really address that, I don't think. Maybe he does, maybe you know him better, and whatever, but to me, that's Rüsen, it's kind of, the politics is taken out. It is all about the individual and how the individual interprets the history rather than sort of social groups and how different groups have different views based on their place in history and whether it is being represented.

For me, my relationship with Rüsen, and his didactics is a theory of a kind of concept of our time and what kind of concept of time the inhabitants of the modernity have, what kind of thinking of time and the people in modernity have. Rüsen is this kind of historical consciousness, our situation is a process and we can learn about this process, we can make history in this sense and this kind of approach has good functions for a woman, or a black person, or a Chinese, or a Brazilian guy, or an African American. It is only a way to go in the modernity. You, a modernity guy, you must learn that your situation is a result of history, only that. You must handle that. And that's my Rüsen.

And you like that, that makes sense, you understand that every person is a product of history.

Yes, it is a kind of humanism, in this sense.

Yes.

And then, there is this dimension of universality, but your point is the difference. When and how did you start studying students in the US?

Well, I got my PHD in 1989, and my doctoral dissertation. Well, I was a high school history teacher, my doctoral dissertation was about using music, and art and poetry to teach history and the question was what the students learned from those kinds of sources that they don't learn from textbooks. So, I was always interested in history and how to teach history and I did that re- 
search for maybe three or four years. Then, I moved to the state of Michigan, and in Michigan, unlike New York City where there is everybody, Brazilian, Chinese, African, Asian - in Michigan, it was mainly white people and black people. And, something Peter Seixas wrote in an article about Canada and how the ethnic background of the student was not being addressed. I thought, I'm going to steal that idea, I'm going to take that idea in the US, and so that is when I started the study in one classroom, where you have black students and white students, siting right next to each other; they have the same teacher, the same textbook, the same lessons, but at the end of the year, they have different interpretations of US History. So, I did that type of study for 15 years. I mean, maybe 8,9 years with data and articles and then $4-5$ years to write the book. But every professor, when you read other people, you get ideas and then you turn them into your own idea and interest. So, I also did that in New Zealand, with white students and Maori (indigenous) students and how they see their history and now I am writing on that. And now I do little things, little projects.

\section{How is the situation of the History Education field in the US?}

(Laughs) When I started there were only Linda Levstik, Peter Seixas (Canadá) and Sam Wineburg, that was it. We saw a field go from almost nothing, because before Linda and Sam, nobody in the US wrote about history education, nobody. They used to fight about should the curriculum be History, or should it be Social Studies. That's what they talked about, stupid, okay? Now, really dozens of young scholars are writing about history education. And it is like, just to read all of it, you can barely keep up. So that is a beautiful thing to see. I mean, here there's a lot to do with Indian and history and black people and history, I don't know, but maybe there's stuff to do.

\section{How do your studies relate to the student's historical experience in the US?}

My history education teachers, students to be teachers, and the students in the research too.

\section{Are there some changes in these students?}

In how they think, in over 20 years? You know, not the high school students, but with university students being trained to be history teachers, I think they 
changed. Okay, 20 years ago, I've been in NY for 20 years, and when I first came, most of the people training to be teachers were white. And most of the students of NYC are not white, and then university students are kind of like afraid to bring up racial issues, like slavery and segregation, they have kind of afraid and do not know what to do, and if a contemporary incident happened like, police killing of black men, they didn't want to talk about it in the classroom, because they were afraid, 20 years ago. Now, my students preparing to be teachers want to know, they understand that they are white, and have different experiences, then, low income poor students of color and they are still afraid, like, how to say, what to say, but they want to understand, and if there is a contemporary bad event, like a police killing, they will talk about it. So, I think, because they come to the university, and they learn not just in education but in history, like you were saying, in high school it is kind of the easy stuff. In university, you understand that people have been oppressed, that there is white privilege, they learn that, and so now they are ready to, at least, think about and try to deal with those difficult racial issues in history, even though they are still kind of afraid.

\section{Which is the contribution of the study of interculturality to the comprehension} of the experience of African American, Islamic, Latin and Chinese students in the US?

One example: I'm not sure if this is what you are getting at, but I did one study where we asked the students, the high school students, all African American, Latino, Asian American, about US History before they took the US class in high school, and basically, they see people like themselves as oppressed, slavery, bad, nothing good. But the teacher wanted to teach them historical agency of people of color, so she taught not just about slavery, but like, slaves who ran away, and slaves who resisted, and they sang songs about freedom, and she did this, not just with slavery, but all through US History. Even Latinos - because we teach nothing about that and NY has millions of Latinos - no history. She taught about that too; you know the Black Panther Party? The African Americans who in the 60's said, we are going to defend ourselves, there was a party like that for Latinos in NY and she taught about them and how they helped Latinos. At the end of the year what we saw is the students did learn and talk about history, so that people of color in history weren't just victims, but they also were actors, they did something to try to make their lives 
better. However, the same teacher also tried to teach the students that not all white people in history were bad, that some white people were abolitionists, tried to get rid of slavery, tried to help black people. But the high school students did not really pick up about this; they still saw white people as kind of the bad, they didn't make a distinction between white people who fought against oppression and other white people who did nothing or worse. I think it is often people of color or the marginalized people who get more rights for all of us. So, to me, that is one of their contributions. I learned this from black people, their view is that black people built the country (as slaves) and when I heard that I was like, wow! But when you think about it, the cotton, the Chinese, the factories, I mean, we use slave labor and Chinese bad labor to build the country even though other people profited. But it is not really a lesson that gets taught in the mainstream. I learned that from black people, and they are right, but we don't teach it that way. We teach it like, oh, poor black people, they were slaves, pobrecitos, no! They built our country. Many universities like Harvard University, Yale University, Brown, the elite, the top Universities, some of their money came from Northern people who were in the slave business. They owned the boats, brought slaves over, made millions of dollars, and in fact Georgetown University, a famous university in Washington, they owned slaves, two or three hundred years ago, and they sold their slaves to buy more land for the university, and there had been student protests over this, and now Georgetown has scholarships for any student who is an ancestor of the slaves that they sold. It is coming out now, that every aspect of US society, even Yale University had founders that were involved with slavery. So, you know, I think the contribution now is, young people of color, students of color in the University are protesting to bring this story out, and to do compensation, like scholarship money, because, you know, the slave labor contributed to Yale, or to Harvard.

The US is a reference of segregation, like, people know that the segregation happens. But in Brazil, because we are so multicultural, and we come from a past that is made of a lot of people joined, we call it a "racial democracy". We didn't have the segregation, it is built like we didn't have it and that is a speech, a story we tell ourselves.

I've read a book about Brazilian sociology and they said Brazilians frame difference more in terms of social class, not race. But the difference is class, 
who has money, who doesn't. In US also, who has money, who doesn't, but it is also connected; money and race go together.

But the fight in fact is of the recognition of this segregation. The African Brazilians want people to know that the segregation happens, and it is not a racial democracy, you must go further, you have to look inside and see that the segregation also happened in the past and today.

And it is not part of the Brazilian story, when slavery ended, they don't really talk about racism in the history.

Black people want to speak about this and see the differences in history and oppression over the slaves and over the African Brazilians, but for us it is very important to say it is different. There is a difference. We are over all the history oppressed, and to stop the racial democracy, stop the notion of the racial democracy. So, history is very important for us to say that. But I was speaking about the USA and I thought that it was obvious, there is a difference, that it is not possible to ignore, pretend. So, is there a difference in the fight of the African Americans, the people of color? The way African Brazilian want to deal with it is to show that they were repressed in the past, they are still repressed, and they don't want to be treated like victims all the time. They want to be recognized for the things that they also did, the contributions, and also want to know if there is a difference in the way we deal with that because in the US the segregation is recognized. In here, it seems like, at first, we have to recognize the segregation and then deal with the problem.

The US is funny, because everyone knows that there has been slavery, segregation, and because, you know the Black Lives Matter protest movement in the last five years or so in response to the police killings of blacks, young people, black, and white and Latino have protested, and said that this happened throughout our history. It is like about the one hand everyone knows about it, yet about the other hand they just don't deal with it. And now with Trump, we were talking, more hate crimes, in US, especially against Muslims, against gay people, against people of color, even in the schools, more bullying of Latinos, white kids say to immigrant kids to go back to your country. Under Obama, he tried to do a few things, especially around police, but under Trump, all that 
goes away. It is not acceptable in public, but it is more vocal, the anti-immigrant, the anti-Muslim, the anti-gay activities. Even though people agree that black people were oppressed, and Latinos were oppressed, I mean some might think they are still not, many understand that they still are, or because my parents might have had some money and then I get the inheritance, black people much less money passed down through generations. Even if people know that, you know, the society in general doesn't care. Everything now is about jobs, and taxes, you know, Trump.

\section{And what do you think about the conditions of the elementary school teachers?}

So, of course, it depends on what city, the suburbs. In NYC every year there are more and more regulations bureaucracy, you know, and not even about instruction. Did the kid show up and so forth? So, teachers feel not appreciated and every time a teacher in NYC does something bad, like, one teacher was caught during lunch smoking marijuana, it becomes front page of news. But the teacher who helps all the children, no story. So, I think teachers feel underappreciated, but in NY there is a strong teacher union, so they do help, and the salaries in NYC used to be very low, now they are a bit better, it is still not great, but it is better, so, yeah, there is just always more regulation at the university as well. Now professors have to fill out more paper work, you know, more and more bureaucracy. But, you know, these teachers are the ones who stay, they love the kids, they love teaching, there is some opportunity for professional development for NYC teachers, but there is just not enough support within the school or within our society, probably like here. I guess everywhere.

\section{NOTA}

${ }^{1}$ Conferência intitulada "Educação Histórica: Quatro abordagens" proferida no I Seminário de Educação Histórica: debates contemporâneos de ensino e pesquisa em História, organizado pela Professora Doutora Maria da Conceição Silva. Agradecemos o financiamento da FULBRIGHT. Também agradecemos o apoio dos estudantes do Curso de Relações Internacionais da Universidade Federal de Goiás, Elisa Cascão Ferreira e Matheus Dornelas e Machado.

Entrevista recebida em 11 de maio de 2020. Aprovada em 3 de agosto de 2020. 